\title{
EVALUASI KESIAPAN GURU FISIKA SMA DALAM KEGIATAN LABORATORIUM DI KOTA MATARAM
}

\author{
M. Isnaini ${ }^{1}$, Khairil Anwar ${ }^{2}$ \\ ${ }^{1,2}$ Dosen Program Studi Pendidikan Fisika FKIP, Universitas Muhammadiyah Mataram \\ Email: iskasipahune@gmail.com, hairil_physic@yahoo.com
}

\begin{abstract}
ABSTRAK
Tujuan penelitian ini adalah untuk mengetahui kesiapan guru fisika SMA dalam kegiatan laboratorium. Kesiapan guru fisika SMA dalam kegiatan laboratorium dapat diketahui dari: (1) kompetensi laboratorium guru fisika SMA dalam merancang kegiatan laboratorium; (2) sarana prasarana laboratorium; (3) hambatanhambatan yang ditemui guru fisika SMA dalam melaksanakan kegiatan laboratorium; dan (4) langkah-langkah guru fisika SMA mengatasi hambatan dalam melaksanakan kegiatan laboratorium, sehingga hasil temuan ini dapat digunakan sebagai masukan bagi: (1) guru fisika SMA untuk meningkatkan kompetensinya dalam kegiatan laboratorium; (2) Kemendikbud, Dinas Dikpora Kota Mataram dan Provinsi NTB untuk meningkatkan kompetensi kegiatan laboratorium guru fisika SMA melalui pelatihan-pelatihan tentang laboratorium; (3) Lembaga Pendidik Tenaga Keguruan (LPTK) diharapkan meningkatkan kualitas lulusan calon guru fisika dalam kegiatan laboratorium. Penelitian ini menggunakan pendekatan deskriptif kualitatif dengan metode pengumulan data berupa dokumentasi, angket, wawancara dan observasi. Populasi penelitian ini adalah guru fisika SMA se-Kota Mataram yang terdiri dari 8 SMA Negeri dan 10 SMA Swasta berjumlah 32 orang. Sampel penelitian adalah 20 orang guru fisika SMA se-Kota Mataram yang terdiri dari 14 guru SMAN, 6 guru SMA Swasta. Ke-20 guru sampel tersebar di 7 SMA Negeri dan 6 SMA Swasta. Berdasarkan informasi dan analisis yang dilakukan kesiapan guru fisika kota mataram dalam kegiatan laboratorium dikategorikan cukup siap, yang dapat dilihat dari: (a) kompetensi guru fisika SMA dalam kegiatan laboratorium cukup baik, yaitu sebesar 52\%, (b) Kondisi sarana prasarana laboratorium fisika kategori cukup baik, yaitu sebesar $63.1 \%$, (c) Faktor penghambat kegiatan laboratorium berupa gedung/ruangan sebesar $56 \%$ dalam ketegori cukup banyak, pengelolaan laboratorium sebesar $70 \%$ berkategori cukup banyak, dan alat dan bahan kegiatan laboratorium, sebesar $56 \%$ berkategori cukup banyak, dan (d) Langkah-langkah dalam mengatasi hambatan kegiatan laboratorium gedung/ruang laboratorium dikategorikan cukup baik, yaitu sebesar $70 \%$, pengelolaan laboratorium berkategori cukup baik, sebesar $57 \%$ dan alat dan bahan kegiatan laboratorium sebesar $58 \%$, dalam ketegori cukup baik. Saran yang dapat diberikan dari hasil penelitian ini adalah diharapkan agar instansi terkait lebih sering memberikan pelatihan terhadap kegiatan laboarotium untuk meningkatkan kompetensi guru dalam kegiatan laboratorium khususnya kegiatan prosedur percobaan inquiri atau keterampilan proses dan alat evaluasi kegiatan laboratorium.
\end{abstract}

Kata Kunci : Evaluasi, Laboratorium, Kompetensi laboratorium

\section{PENDAHULUAN}

Salah satu tema dalam kurikulum 2013 adalah penyederhanaan, dan tematikintegratif. Kurikulum 2013 disiapkan untuk mencetak generasi yang siap di dalam menghadapi masa depan. Karena itu, kurikulum disusun untuk mengantisipasi perkembangan masa depan. Titik beratnya, kurikulum 2013 bertujuan untuk mendorong peserta didik atau siswa, mampu lebih baik dalam melakukan observasi, bertanya, bernalar, dan mengkomunikasikan (mempresentasikan) apa yang mereka peroleh atau mereka ketahui setelah menerima materi pembelajaran (Badan Penelitian dan Pengembangan, 2012). Dalam proses pembelajaran, kegiatan-kegiatan seperti observasi, bertanya, bernalar, dan mengkomunikasikan merupakan bagian dari keterampilan proses sains, seperti yang dikemukakan oleh Brotherton (1995) dan Dahar (2012).

Karakteristik pembelajaran IPA Fisika di sekolah mengutamakan kerja ilmiah sehingga siswa dapat bersikap ilmiah (termasuk di dalamnya keterampilan proses), selanjutnya konsep yang telah dikuasai akan diterapkan dalam usaha pemenuhan 
kebutuhan hidup. Tuntutan pembelajaran IPA tidak mungkin dapat terpenuhi apabila tidak didukung oleh kemampuan guru dalam menyelenggarakan kegiatan laboratorium sebagai kunci keberhasilan pembelajaran IPA (Alit, 2011). Menurut Wiyanto (2008) ada tujuh kompetensi laboratorium guru terkait merancang dan melaksanakan kegiatan laboratorium (kompetensi laboratorium) yaitu; (1) menentukan tujuan penyelenggaraan kegiatan laboratorium bagi siswa; (2) menentukan jenis percobaan yang sesuai dengan tujuan yang telah ditetapkan; (3) mengenali alat-alat laboratorium dan terampil menggunakannya; (4) mengenali rangkaian percobaan dan menggambarkan diagramnya; (5) merencanakan prosedur percobaan dan melaksanakannya; (6) menyusun petunjuk kegiatan laboratorium dan mengimplementasikannya; (7) merancang alat evaluasi kegiatan laboratorium.

Hasil penelitian Nur (2004), memberikan petunjuk bahwa kegiatan laboratorium IPA yang memungkinkan siswa bekerja ilmiah mengikuti prosedur keterampilan proses sains belum terlaksana. Menurut Wenning (2005), semua guru fisika harus memiliki semua kompetensi yang terdapat dalam kerja ilmiah tersebut untuk meningkatkan kualitas pembelajaran fisika. Saat ini timbul dugaan bahwa kemampuan guru dalam merancang dan melaksanakan kegiatan laboratorium masih rendah, sehingga guru tidak melaksanakan kegiatan laboratorium yang menekankan keterampilan proses dalam pembelajaran. Dugaan itu didukung hasil penelitian Balitbang Depdiknas (Rustad dkk, 2004) yang menunjukan bahwa sekitar 43\% guru fisika SMU di Indonesia tidak dapat menggunakan alat-alat laboratorium yang tersedia di sekolahnya, sehingga tingkat pemanfaatan alat-alat itu dalam pembelajaran cenderung rendah.

Dengan diterapkanya kurikulum 2013 dan tuntutan pembelajaran IPA Fisika yang menekankan pada kegiatan laboratorium, timbul pertanyaan apakah guru fisika SMA di Kota Mataram siap melaksanakan kegiatan laboratorium tersebut? Untuk melihat kesiapan guru fisika dalam melaksanakan kegiatan laboratorium dapat dilihat dari kompetensi guru fisika dalam melaksanakan kegiatan laboratorium, sarana prasarana, hambatan-hambatan guru dalam melaksanakan kegiatan laboratorium dan cara/solusi mengatasi hambatan tersebut.

Ada beberapa hal yang menjadikan penelitian ini perlu dilaksanakan:

a. Berkaitan tuntutan pelaksanaan kurikulum 2013 dan pembelajaran fisika yang mendorong siswa melakukan keterampilan proses sains, maka sangat diperlukan pembelajaran yang menekankan kegiatan laboratorium sehingga perlu dilakukan evaluasi terhadap kesiapan guru dalam melaksanakan kegiatan laboratorium.

b. Hasil penelitian Sriyono \& Hamid (2003), Nur (2004), dan Bambang Sumintono (2010) menunjukan bahwa kegiatan laboratorium IPA belum terlaksana secara optimal, sehingga perlu dilakukan penelitian yang serupa untuk wilayah Kota Mataram agar dapat diketahui bagaimana kompetensi guru, sarana dan parasarana, hambatan-hambatan serta cara mengatasi hambatan tersebut dalam kaitannya dengan kegiatan laboratorium.

Berdasarkan latar belakang dan urgensi penelitian ini, maka masalah utama dalam penelitian ini adalah bagaimana kesiapan guru fisika SMA di Kota Mataram dalam kegiatan laboratorium?. Adapun masalah-masalah yang diteliti dapat dirumuskan sebagai berikut:

a. Bagaimana kompetensi laboratorium guru fisika SMA di Kota Mataram dalam melaksanakan kegiatan laboratorium yang dapat terlihat dari:

1) Bagaimana kompetensi guru dalam menentukan tujuan penyelenggaraan kegiatan laboratorium bagi siswa?

2) Bagaimana kompetensi guru dalam menentukan jenis percobaan yang sesuai?

3) Bagaimana kompetensi guru dalam mengenali alat-alat laboratorium? 
4) Bagaimana kompetensi guru dalam mengenali rangkaian percobaan?

5) Bagaimana kompetensi guru dalam merencanakan prosedur percobaan?

6) Bagaimana kompetensi guru dalam menyusun petunjuk kegiatan laboratorium?

7) Bagaimana kompetensi guru dalam merancang alat evaluasi kegiatan laboratorium?

b. Bagaimana sarana dan prasarana laboratorium fisika SMA di Kota Mataram?

c. Hambatan-hambatan apakah yang ditemui guru fisika SMA di Kota Mataram dalam melaksanakan kegiatan laboratorium?

d. Bagaimana cara guru fisika SMA di Kota Mataram mengatasi hambatan-hambatan yang terjadi dalam kegiatan laboratorium?

Tujuan yang ingin dicapai dalam penelitian ini adalah mengetahui kesiapan guru fisika SMA di Kota Mataram dalam kegiatan laboratorium yang diketahui dari: (1) kompetensi laboratorium guru fisika SMA di Kota Mataram dalam merancang kegiatan laboratorium; (2) hambatan-hambatan apakah yang ditemui guru fisika SMA di Kota Mataram dalam melaksanakan kegiatan laboratorium; dan (3) langkah-langkah guru fisika SMA di Kota Mataram mengatasi hambatan dalam melaksanakan kegiatan laboratorium.

\section{METODE PENELITIAN}

Penelitian ini adalah penelitian deskriptif kualitatif yang bertujuan mengetahui kesiapan guru fisika SMA dalam melaksanakan kegiatan laboratorium. Kesiapan guru dalam melaksanakan kegiatan laboratorium dapat diketahui dari kompetensi guru fisika dalam melaksanakan kegiatan laboratorium, sarana prasarana, hambatanhambatan guru dalam melaksanakan kegiatan laboratorium dan cara/solusi mengatasi hambatan tersebut.

Populasi sekaligus sampel dalam penelitian ini adalah seluruh guru fisika SMA di wilayah Kota Mataram yang berjumlah 32 orang, tersebar pada 8 SMA Negeri dan 14 SMA Swasta. Sampel penelitian adalah 20 orang guru fisika, yang terdiri dari 14 guru fisika di SMA Negeri dan 6 guru fisika di SMA Swasta.

Alat untuk pengumpulan data yang akan digunakan berbentuk dokumentasi, angket wawancara dan observasi, digunakan untuk mengolah informasi dan penarikan kesimpulan. Sumber data dan instrument penelitian juga standar penilaian untuk penarikan kesimpulan dapat dilihat pada Tabel 1 dan Tabel 2.

Tabel 1. Sumber Data dan Instrumen Penilaian

\begin{tabular}{|c|c|c|c|c|}
\hline No. & Komponen & Sumber Data & Metode & Instrumen \\
\hline 1. & $\begin{array}{l}\text { Kompetensi } \\
\text { Laboratorium } \\
\text { Guru }\end{array}$ & $\begin{array}{c}\text { Dokumentasi } \\
\text { rancangan } \\
\text { praktikum }\end{array}$ & D & $\begin{array}{c}\text { Pedoman } \\
\text { penilaian } \\
\text { kompetensi } \\
\text { laboratorium }\end{array}$ \\
\hline 3. & $\begin{array}{l}\text { Sarana Prasarana } \\
\text { Hambatan Kegiatan }\end{array}$ & $\begin{array}{c}\text { Ruang } \\
\text { laboratorium }\end{array}$ & $\begin{array}{l}\text { Obs. \& } \\
\text { W }\end{array}$ & $\begin{array}{l}\text { Pedoman } \\
\text { obervasi }\end{array}$ \\
\hline \multirow[t]{2}{*}{4.} & Laboratorium & Guru & $A \& W$ & laboratorium \\
\hline & $\begin{array}{l}\text { Langkah-langkah } \\
\text { mengatasi } \\
\text { hambatan kegiatan lab. }\end{array}$ & Guru & $A \& W$ & $\begin{array}{l}\text { Angket, dan } \\
\text { wawancara }\end{array}$ \\
\hline
\end{tabular}


Analisis instrument-instrumen komponen penilaian menggunakan pendekatan deskriptif kualitatif dengan standar penilaian menggunakan rumus:

$$
\text { Standar Penilaian }=\frac{\text { Perolehan Jumlah Skor }}{\text { Jumlah Skor Maksimum }} \times 100 \%
$$

Dalam menentukan penilaian, baik sekali baik sekali, baik, cukup baik, dan kurang dapat diperoleh melalui Tabel 2 Standar Penilaian.

Tabel 2. Standar Penilaian

\begin{tabular}{|c|c|c|}
\hline Standar Penilaian & Penilaian & Keterangan \\
\hline $91-100 \%$ & Baik Sekali & \multirow{4}{*}{$\begin{array}{c}\text { Penilaian dilakukan pada } \\
\text { setiap aspek atau secara } \\
\text { keseluruhan }\end{array}$} \\
\hline $76-90 \%$ & Baik & \\
\hline $56-75 \%$ & Cukup Baik & \\
\hline $0-55 \%$ & Kurang Baik & \\
\hline
\end{tabular}

\section{HASIL PENELITIAN}

A. Kompetensi Laboratorium Guru Fisika

Berdasarkan data dokumen LKS yang dibuat oleh guru fisika SMA di Kota Mataram dan angket yang diberikan, peneliti melakukan analisis untuk memperoleh informasi mengenai kompetensi guru fisika SMA di Kota Mataram dalam kegiatan laboratorium. Hasil analisis dapat dilihat pada Tabel 3 Kompetensi Penyusunan LKS Guru Fisika di Kota Mataram.

Tabel 3. Kompetensi Penyusunan LKS Guru Fisika di Kota Mataram

\begin{tabular}{|c|c|c|c|c|c|c|c|c|c|}
\hline \multirow{3}{*}{ No } & \multirow{3}{*}{ Indikator } & \multicolumn{6}{|c|}{ Ada } & \multicolumn{2}{|c|}{ Tidak Ada } \\
\hline & & \multicolumn{2}{|l|}{$\mathrm{BS}$} & \multicolumn{2}{|l|}{ B } & \multicolumn{2}{|l|}{ CB } & \multicolumn{2}{|l|}{$\mathrm{K}$} \\
\hline & & Jml & $\%$ & $\mathrm{Jml}$ & $\%$ & $\mathrm{Jml}$ & $\%$ & $\mathrm{Jml}$ & $\%$ \\
\hline 1 & $\begin{array}{l}\text { Menentukan tujuan } \\
\text { penyelenggaraan kegiatan lab. } \\
\text { bagi siswa. }\end{array}$ & - & - & 13 & $32.5 \%$ & 7 & $17.5 \%$ & 20 & $50 \%$ \\
\hline 2 & $\begin{array}{l}\text { Menentukan jenis percobaan } \\
\text { yang sesuai dengan tujuan } \\
\text { yang telah ditetapkan }\end{array}$ & - & - & - & - & 22 & $55 \%$ & 18 & $45 \%$ \\
\hline 3 & Mengenali alat-alat lab & - & - & 11 & $27.5 \%$ & 12 & $30 \%$ & 17 & $42.5 \%$ \\
\hline 4 & $\begin{array}{l}\text { Mengenali rangkaian } \\
\text { percobaan }\end{array}$ & - & - & 10 & $25 \%$ & 18 & $45 \%$ & 12 & $30 \%$ \\
\hline 5 & $\begin{array}{l}\text { Merencanakan prosedur } \\
\text { percobaan }\end{array}$ & - & - & 15 & $10.7 \%$ & 30 & $21.4 \%$ & 95 & $67.9 \%$ \\
\hline 6 & $\begin{array}{l}\text { Menyusun petunjuk kegiatan } \\
\text { laboratorium }\end{array}$ & - & - & - & - & 7 & $35 \%$ & 13 & $65 \%$ \\
\hline 7 & $\begin{array}{l}\text { Merancang alat evaluasi } \\
\text { kegiatan laboratorium }\end{array}$ & - & - & - & - & 1 & $5 \%$ & 19 & $95 \%$ \\
\hline & Jumlah & - & - & 49 & $12.9 \%$ & 96 & $25.3 \%$ & 235 & $61.8 \%$ \\
\hline
\end{tabular}




\section{B. Sarana dan Prasarana}

Data sarana prasarana laboratorium diperoleh dari kegiatan observasi dan wawancara dengan petugas laboratorium (Kepala Laboratorium, Laboran, Guru Fisika), hasil observasi dan wawancara dapat dilihat pada Tabel 4. Sarana dan Prasarana Laboratorium.

Tabel 4. Sarana dan Prasarana Laboratorium

\begin{tabular}{|c|c|c|c|c|c|}
\hline \multirow{2}{*}{ No } & \multirow{2}{*}{ Jenis } & \multirow{2}{*}{ Rasio } & \multicolumn{3}{|c|}{ Deskripsi Keadaan } \\
\hline & & & $\mathrm{Ya}$ & Tidak & Tidak ada \\
\hline 1 & Gedung/Ruang & \multirow{6}{*}{ 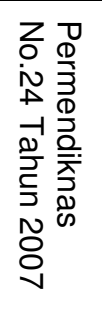 } & $23.1 \%$ & $26.9 \%$ & $50 \%$ \\
\hline 2 & Perabot & & $60.4 \%$ & $8.8 \%$ & $30.8 \%$ \\
\hline 3 & $\begin{array}{l}\text { Bahan Dan Alat Ukur } \\
\text { Dasar }\end{array}$ & & $19.8 \%$ & $39.6 \%$ & $40.5 \%$ \\
\hline 4 & Alat Percobaan & & $33.7 \%$ & $32.5 \%$ & $33.7 \%$ \\
\hline 5 & Media Pendidikan & & $70 \%$ & $30 \%$ & $0 \%$ \\
\hline 6 & Perlengkapan lain & & $42.3 \%$ & $21.8 \%$ & $35.9 \%$ \\
\hline & Jumlah & & $36.9 \%$ & $26.2 \%$ & $36.9 \%$ \\
\hline
\end{tabular}

\section{Hambatan dan Langkah-langkah Mengatasi Hambatan Kegiatan Laboratorium}

Hambatan kegiatan laboratorium terdiri dari tiga bagian, yaitu hambatan pada sarana dan prasarana laboratorium, hambatan pengelolaan laboratorium dan hamabatan alat bahan laboratorium. Agar kegiatan laboratorium dapat berjalan dengan maksimal, hambatan-hambatan yang di alami guru fisika dalam kegiatan laboratorium, perlu untuk dicarikan solusi. Bagaimana cara guru fisika dalam mencari solusi terhadap hambatan-hambatan yang dirasakan, dapat dillihat pada Tabel 5 Langkah-langkah Mengatasi Hambatan Kegiatan Laboratorium.

Hasil penelitian menunjukan hambatan kegiatan laboratorium dari segi sarana dan prasarana berupa tidak memiliki gedung/ ruang laboratorium sebanyak $20 \%$, kelayakan gedung $30 \%$, perlengkapan laboratorium $20 \%$ dan sarana utilitas $32 \%$. Langkah-langkah guru fisika mengatasi hambatan sarana dan prasarana dapat dilihat pada Tabel $5 \mathrm{a}$.

Tabel 5a. Langkah-langkah Mengatasi Hambatan Kegiatan Laboratorium

\begin{tabular}{|c|c|c|c|c|}
\hline No & Indikator & Temuan & jumlah & $\%$ \\
\hline \multicolumn{5}{|c|}{ A. Sarana dan Prasarana } \\
\hline \multirow[t]{9}{*}{1} & Ruangan Laboratorium & & & \\
\hline & a. Ruang gelap & a. Memiliki & 4 & $20 \%$ \\
\hline & & b. Tidak memilik & 16 & $80 \%$ \\
\hline & b. Ruang persiapan & a. Memenuhi syarat & 4 & $20 \%$ \\
\hline & praktikum & b. Kurang memenuhi syarat & 6 & $30 \%$ \\
\hline & & c. Tidak memiliki & 10 & $50 \%$ \\
\hline & c. Ruang penyimpanan alat & a. Memenuhi syarat & 10 & $50 \%$ \\
\hline & dan bahan & b. Kurang memenuhi syarat & 6 & $30 \%$ \\
\hline & & c. Tidak memiliki & 4 & $20 \%$ \\
\hline \multirow[t]{5}{*}{2} & Perlengkapan laboratorium & & & \\
\hline & a. Meja demonstrasi & a. Ada memenuhi syarat & 10 & $50 \%$ \\
\hline & & b. Tidak memenuhi syarat & 6 & $30 \%$ \\
\hline & & c. Tidak punya & 4 & $20 \%$ \\
\hline & b. Meja praktikum & a. Memiliki ketentuan & 15 & $75 \%$ \\
\hline
\end{tabular}




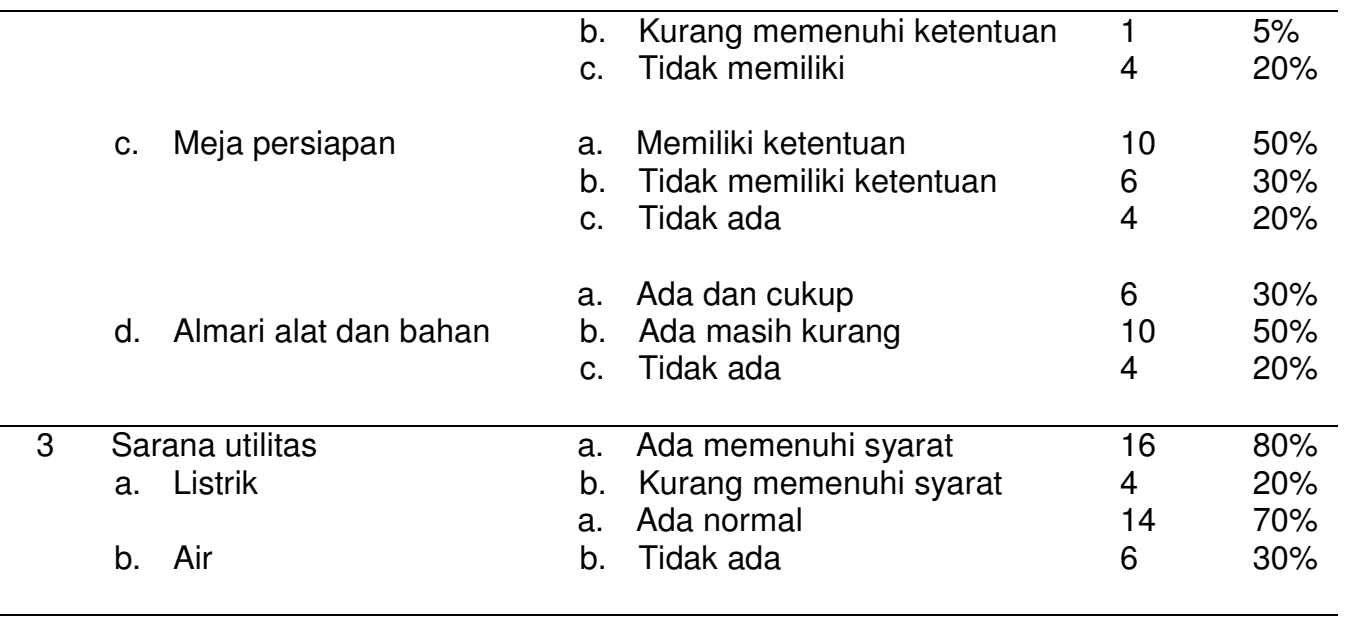

Hambatan kegiatan laboratorium selanjutnya adalah hambatan pengelolaan laboratorium berupa administrasi laboratorium yang terdiri dari buku inventarisasi $30 \%$, buku peminjaman alat dan bahan $30 \%$, buku perawatan alat dan bahan 30\%, buku pedoman penggunaan alat $60 \%$, buku rancangan kegiatan laboratorium 57\% (khusus LKS inkuiri $85 \%$ ), alat evaluasi kegiatan laboratorium $95 \%$ dan buku laporan hasil kegiatan laboratorium 75\%. Untuk hambatan administrasi berupa perawatan laboratorium $20 \%$, pengaturan kegiatan laboratorium $40 \%$, struktur organisasi $25 \%$, dan pegawai khusus lab 25\%. Langkah-langkah guru fisika untuk mengatasi hambatan pengelolaan laboratorium dapat dilihat pada Tabel $5 b$.

Tabel 5b. Langkah-langkah Mengatasi Hambatan Kegiatan Laboratorium

\begin{tabular}{|c|c|c|c|c|}
\hline No & Indikator & Temuan & jumlah & $\%$ \\
\hline \multicolumn{5}{|c|}{ B. Pengelolaan laboratorium } \\
\hline \multirow[t]{11}{*}{4} & \multicolumn{4}{|l|}{ Administrasi laboratorium } \\
\hline & \multirow{2}{*}{$\begin{array}{l}\text { a. Buku inventaris } \\
\text { alat/bahan }\end{array}$} & a. Memiliki & 14 & $70 \%$ \\
\hline & & b. Tidak memiliki & 6 & $30 \%$ \\
\hline & \multirow{2}{*}{ b. Buku perawatan alat } & a. Memiliki & 14 & $70 \%$ \\
\hline & & b. Tidak memiliki & 6 & $30 \%$ \\
\hline & \multirow{2}{*}{$\begin{array}{l}\text { c. Buku petunjuk } \\
\text { penggunaan alat }\end{array}$} & a. Memiliki & 8 & $40 \%$ \\
\hline & & b. Tidak memiliki & 12 & $60 \%$ \\
\hline & \multirow{2}{*}{$\begin{array}{l}\text { d. Buku rancangan } \\
\text { kegiatan laboratorium }\end{array}$} & a. memiliki & 14 & $70 \%$ \\
\hline & & b. Tidak memiliki & 6 & $30 \%$ \\
\hline & \multirow{2}{*}{$\begin{array}{l}\text { e. Buku laporan hasil } \\
\text { kegiatan laboratorium }\end{array}$} & a. Memiliki & 5 & $25 \%$ \\
\hline & & b. Tidak memiliki & 15 & $75 \%$ \\
\hline \multirow[t]{3}{*}{5} & \multirow{3}{*}{$\begin{array}{l}\text { Pengelolaan dan } \\
\text { pengembangn lab. Fisika } \\
\text { a. Guru }\end{array}$} & & & \\
\hline & & a. Pernah pelatihan pengelolaan & 11 & $55 \%$ \\
\hline & & $\begin{array}{l}\text { b. Belum Pernah pelatihan } \\
\text { pengelolaan lab dan } \\
\text { perawatan lab }\end{array}$ & 9 & $45 \%$ \\
\hline
\end{tabular}


b. Laboran

c. Pengembangan laboratorium

d. Alat evaluasi kegiatan laboratorium

e. LKS inquiri/ keterampilan proses

f. Waktu Penggunaan laboratorium a. Memiliki dan sesuai ketentuan $7 \quad 35 \%$

b. Memiliki tidak sesuai $\quad 8 \quad 40 \%$

ketentuan

c. Tidak memiliki laboran $\quad 5 \quad 35 \%$

a. Kerjasama dgn sekolah/ 3 instansi lain, penelitian inovasi

b. Penelitian/ inovasi dalam $525 \%$ bidang fisika

c. Tidak ada bentuk $12 \quad 60 \%$ pengembangan

a. Evaluasi secara subjektif $\quad 13 \quad 65 \%$

b. Tidak melakukan kegiatan $735 \%$ evaluasi

a. BIm paham kegiatan inquiry/ $12 \quad 60 \%$ keterampilan proses

b. Waktu kegiatan lab terlalu $\quad 8 \quad 40 \%$ lama

a. Menunda Praktikum $8 \quad 40 \%$

b. Melakukan demontrasi di kelas $12 \quad 60 \%$

Hambatan kegiatan laboratorium yang terakhir adalah hambatan alat dan bahan laboratorium yang terdiri dari jumlah alat praktikum $55 \%$, kondisi alat praktikum $20 \%$, jenis alat yang tidak layak digunakan dalam kegiatan praktikum adalah mekanika dan kalor 50\%, Gelombang Optik $10 \%$, Elektromagnet $30 \%$, dan alat-alat ukur 10\%. Selanjutnya hambatan alat dan bahan laboratorium adalah perawatan dan perbaikan alat $20 \%$, membuat alat sederhana $45 \%$, dan penambahan alat $70 \%$. Langkah-langkah guru fisika untuk mengatasi hambatan alat dan bahan laboratorium dapat dilihat pada Tabel 5c.

Tabel 5b. Langkah-langkah Mengatasi Hambatan Kegiatan Laboratorium

\begin{tabular}{|c|c|c|c|c|}
\hline No & Indikator & Temuan & jumlah & $\%$ \\
\hline \multicolumn{5}{|c|}{ C. Alat dan bahan praktikum } \\
\hline \multirow[t]{10}{*}{6} & Kondisi Alat Bahan Praktikum & & & \\
\hline & a. Jumlah alat/bahan & a. Memenuhi kebutuhan & 11 & $55 \%$ \\
\hline & praktikum & b. Membuat alat sederhana & 9 & $45 \%$ \\
\hline & b. Alat praktikum hanya satu & & & \\
\hline & unit & a. Bergilir & 8 & $40 \%$ \\
\hline & & b. Demonstrasi & 12 & $60 \%$ \\
\hline & c. Sekolah tidak memiliki & & & \\
\hline & alat & a. Membuat alat sederhana & 9 & $45 \%$ \\
\hline & & b. Membeli alat baru & 8 & $40 \%$ \\
\hline & & $\begin{array}{l}\text { c. Tidak membuat dan membeli } \\
\text { alat }\end{array}$ & 3 & $15 \%$ \\
\hline \multirow[t]{4}{*}{7} & Perbaikan alat yang rusak & & & \\
\hline & a. Mekanika dan gelombang & a. Diperbaiki sendiri & 9 & $45 \%$ \\
\hline & & b. Diperbaiki orang lain & 7 & $35 \%$ \\
\hline & & c. Tidak diperbaiki & 4 & $20 \%$ \\
\hline
\end{tabular}




\begin{tabular}{|c|c|c|c|c|c|}
\hline & b. Optic & $\begin{array}{l}\text { a. } \\
\text { b. } \\
\text { c. }\end{array}$ & $\begin{array}{l}\text { Diperbaiki sendiri } \\
\text { Diperbaiki orang lain } \\
\text { Tidak diperbaiki }\end{array}$ & $\begin{array}{l}2 \\
7 \\
11\end{array}$ & $\begin{array}{l}10 \% \\
35 \% \\
55 \%\end{array}$ \\
\hline & c. Elektromagnetik & $\begin{array}{l}\text { a. } \\
\text { b. } \\
\text { c. }\end{array}$ & $\begin{array}{l}\text { Diperbaiki sendiri } \\
\text { Diperbaiki orang lain } \\
\text { Tidak diperbaiki }\end{array}$ & $\begin{array}{l}7 \\
9 \\
4\end{array}$ & $\begin{array}{l}35 \% \\
45 \% \\
20 \%\end{array}$ \\
\hline & $\begin{array}{l}\text { d. Kalor dan } \\
\text { termmodinamika }\end{array}$ & $\begin{array}{l}\text { a. } \\
\text { b. } \\
\text { c. }\end{array}$ & $\begin{array}{l}\text { Diperbaiki sendiri } \\
\text { Diperbaiki orang lain } \\
\text { Tidak diperbaiki }\end{array}$ & $\begin{array}{l}5 \\
10 \\
5\end{array}$ & $\begin{array}{l}25 \% \\
50 \% \\
50 \%\end{array}$ \\
\hline & e. Alat-alat ukur & $\begin{array}{l}\text { a. } \\
\text { b. } \\
\text { c. }\end{array}$ & $\begin{array}{l}\text { Diperbaiki sendiri } \\
\text { Diperbaiki orang lain } \\
\text { Tidak diperbaiki }\end{array}$ & $\begin{array}{l}5 \\
9 \\
6\end{array}$ & $\begin{array}{l}25 \% \\
45 \% \\
30 \%\end{array}$ \\
\hline 8 & Penataan dan perawatan & a. & $\begin{array}{l}\text { Ditata dan dikelompokan } \\
\text { sesuai jenis } \\
\text { Ditata dan dikelompokan tapi } \\
\text { tidak teratur } \\
\text { Tidak ditata }\end{array}$ & $\begin{array}{l}5 \\
6\end{array}$ & $\begin{array}{l}25 \% \\
30 \% \\
45 \%\end{array}$ \\
\hline 9 & Penambahan alat praktikum & a. & $\begin{array}{l}\text { Menunggu bantuan } \\
\text { pemerintah } \\
\text { Menggunakan anggaran } \\
\text { sekolah }\end{array}$ & 11 & $\begin{array}{l}55 \% \\
45 \%\end{array}$ \\
\hline
\end{tabular}

\section{PEMBAHASAN}

Pembelajaran fisika pada dasarnya adalah proses belajar mangajar yang menekankan perolehan konsep pada siswa dengan melakukan pendekatan proses sains, sesuai harapan kurikulum 2013. Tuntutan pembelajaran IPA dan harapan kurikulum 2013 tidak mungkin dapat terpenuhi apabila tidak didukung oleh kemampuan guru dalam menyelenggarakan kegiatan laboratorium, kemampuan ini disebut kompetensi laboratorium. Ada tujuh kompetensi laboratorium guru terkait merancang dan melaksanakan kegiatan laboratorium (kompetensi laboratorium) yaitu; (1) menentukan tujuan penyelenggaraan kegiatan laboratorium bagi siswa; (2) menentukan jenis percobaan yang sesuai dengan tujuan yang telah ditetapkan; (3) mengenali alat-alat laboratorium dan terampil menggunakannya; (4) mengenali rangkaian percobaan dan menggambarkan diagramnya; (5) merencanakan prosedur percobaan dan melaksanakannya; (6) menyusun petunjuk kegiatan laboratorium dan mengimplementasikannya; (7) merancang alat evaluasi kegiatan laboratorium.

Kompetensi guru fisika dalam kegiatan laboratorium yang tercermin dari penyusunan LKS yang dibuat oleh guru fisika SMA di Kota Mataram yaitu:

1) Kompetensi laboratorium guru fisika dalam menentukan tujuan penyelenggaraan kegiatan laboratorium bagi siswa sebanyak $32.5 \%$ guru fisika dalam kategori baik, $17.5 \%$ guru cukup baik dan $50 \%$ guru fisika dalam ketegori kurang. Dari temuan pada rancangan kegiatan laboratorium/ LKS sebagian besar guru belum menuliskan tujuan kegiatan laboratorium dan belum menetapkan indikator yang spesifik dan operasional dari kegiatan yang dilakukan.

2) Kompetensi laboratorium guru fisika dalam menentukan jenis percobaan yang sesuai dengan tujuan yang telah ditetapkan dengan cara memilih percobaan berdasarkan hasil percobaan yang sejenis digunakan oleh $55 \%$ guru 
fisika dalam kategori cukup baik, tetapi hanya $45 \%$ guru fisika yang menjelaskan dasar teori percobaan yang dipilih. Temuan ini memperlihatkan bahwa sebagian besar kegiatan praktikum yang dilakukan masih menggunakan pendekatan verifikasi konsep.

\section{Kompetensi laboratorium}

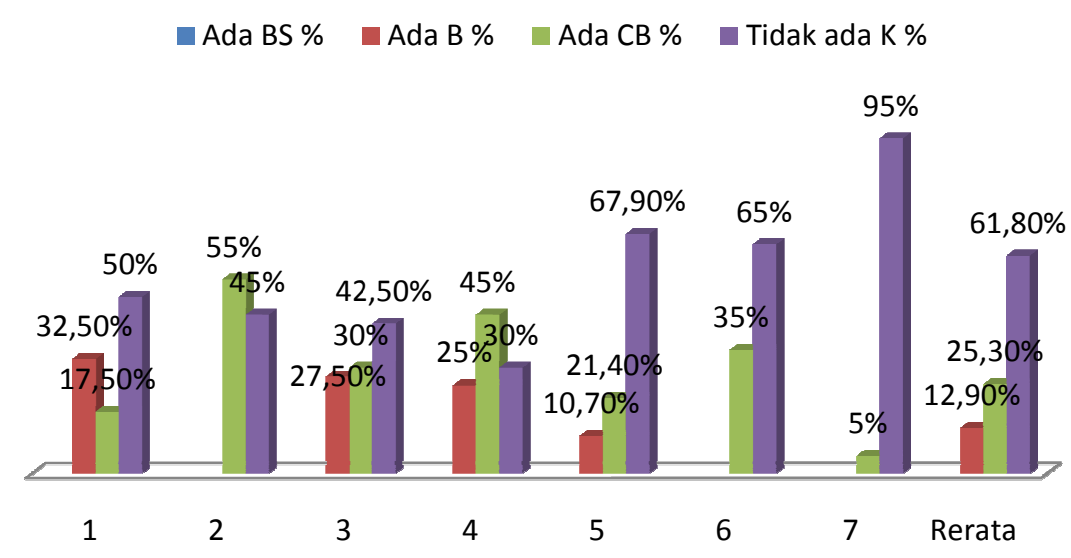

Gambar 01. Grafik Kompetensi Laboratorium Guru Fisika di Kota Mataram

3) Kompetensi laboratorium guru fisika dalam mengenali alat-alat laboratorium, terlihat sebanya $27.5 \%$ guru dalam kategori baik dan $30 \%$ kategori cukup baik dan $42.5 \%$ guru dalam kategori kurang. Dalam rancangan kegiatan laboratorium yang digunakan sebagian besar guru mengenali alat dan bahan percobaan dan hanya sebagian kecil guru fisika yang menjelaskan spesifikasi alat dan bahan yang akan digunakan.

4) Kompetensi laboratorium dalam mengenali rangkaian percobaan dan menggambar diagramnya, $25 \%$ guru dalam kategori baik mengenali symbol alat bahan percobaan dan menggambarakan diagram rangkaian percobaan , 45\% guru dalam ketegori cukup baik dalam mengenali symbol alat dan bahan tetapi tidak menggambarkan diagram rangkaian percobaan. Dan $30 \%$ guru tidak membuat diagram dan menggambar rangkaian.
5) Kompetensi laboratorium dalam merencanakan prosedur percobaan, terlihat $15 \%$ guru baik dalam merencanakan rangkaian percobaan tetapi masih belum merumuskan masalah, mengajukan hipotesis, dan merancang prosedur percobaan (variabel). Ini mengindikasikan hanya guru tersebut belum menggunakan pendekatan inquiry dalam kegiatan laboarotorium. Sebanyak $21.4 \%$ guru dalam ketegori cukup baik masih menggunakan pendekatan keterampilan proses atau demonstrasi. Dan $67 \%$ guru dalam ketegori kurang dalam melakukan kegiatan proses sains.

6) Kompetensi laboratorium dalam menyusun kegiatan laboratorium dengan membuat pertanyaan-pertanyaan yang sesuai untuk menuntun siswa sampai memperoleh kesimpulan, terlihat ada $35 \%$ guru dalam kategori cukup baik dan $65 \%$ guru dalam ketegori kurang karena hanya mengandalkan data tabel yang 
diperoleh. Guru hanya mengandalkan data tabel yang diperoleh tetapi tidak membuat pertanyaan yang menuntun siswa untuk memperoleh kesimpulan secara mandiri.

7) Yang terkahir adalah kompetensi laboratorium guru dalam merancang alat evaluasi kegiatan laboratorium. Sebanyak $100 \%$ guru fisika tidak membuat alat evaluasi kegiatan laboratorium, yang guru lakukan hanya melakukan pengamatan terhadap keaktifan siswa tidak membuat alat evaluasi. Ini memperlihatkan kompetensi guru dalam merancang alat evaluasi masih kurang.

Dari tujuh kompetensi guru dalam menyusun kegiatan laboratorium, jika dikelompokan berdasarkan akumulasi penilaian LKS masing-masing guru, diperoleh nilai 937,3 dengan distandar penilaian 52\% dalam kategori cukup baik. Dari temuan rancangan kegiatan laboratorium yang disusun oleh guru pada umumnya masih dalam pendekatan verifikasi konsep, bahkan ada guru hanya mengandalkan kegiatan laboratorium dari buku paket. Pendekatan verifikasi konsep bukan tidak baik, tetapi sangat kurang dalam melatih kemampuan siswa dalam merumuskan masalah, mencari jawaban sementara dan merancang prosedur percobaan. Kemampuan-kemampuan ini sangat penting mengembankan kemampuan berpikir kritis dan kreatif siswa.

Kondisi sarana prasarana laboratorium fisika di kota mataram secara umum dalam kategori cukup baik sebesar $63,1 \%$. Kategori ini diperoleh dari rincian ruangan laboratorium SMA di Kota Mataram dalam kategori baik dimana kondisi ruangan alat bahan laboratorium sesuai dengan ketentuan Permendiknas No.24 Tahun 2007 adalah $23,1 \%$ baik, $26,9 \%$ cukup baik dan $50 \%$ kurang baik. Hambatan berupa Sarana perabotan menunjukan $63,7 \%$ kategori baik, $5,5 \%$ cukup baik dan 30,8\% kategori kurang. Untuk hambatan alat dan bahan, sebanyak $19,8 \%$ baik, $39,6 \%$ baik, dan $40,5 \%$ atat dan bahan laboratorium fisika dalam kondisi kurang. Hambatan berupa alat percobaan $33,7 \%$ dalam ketegori baik, $32,5 \%$ cukup baik, dan $33,7 \%$ kurang baik. Dan terakhir media dan perlengkapan lain $42,3 \%$ baik, $21,8 \%$ dan $35,9 \%$ kurang. Secara keseluruhan, kondisi sarana dan prasarana dari tiga belas SMA di Kota Mataram yaitu $36,9 \%$ dalam kategori baik, 26,2\% cukup baik, dan $36,9 \%$ kurang baik.

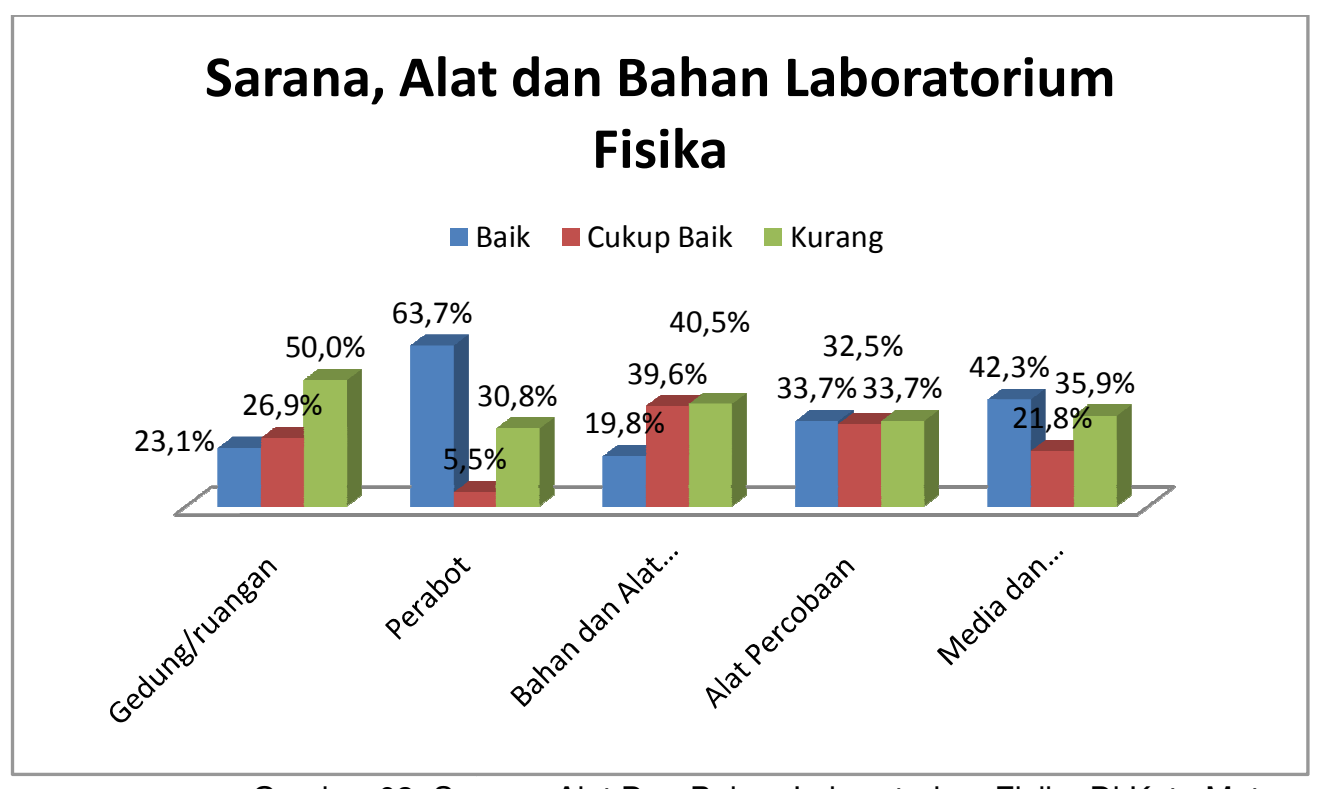

Gambar 02. Sarana, Alat Dan Bahan Laboratorium Fisika Di Kota Mataram 
Berdasarkan angket dan wawancara yang dilakukan terhadap guru fisika di kota Mataram, hambatan-hambatan dalam melakukan kegiatan laboratorium diantaranya dapat dikelompokan menjadi ruangan laboratorium, pengelolaan dan administrasi laboratorium, dan alat bahan laboratorium.

a) Sarana dan prasarana gedung/ruang laboratorium tidak banyak mengalami hambatan, sebanyak 23.1\% gedung/ruang laboratorium dalam kategori baik yang dicirikan dari keberadaan laboratorium yang terpisah dari laboratorium IPA, tidak menjadi ruang kelas dan sesuai dengan prasyarat, $26.9 \%$ kategori cukup yang dicirikan tidak sesuai dengan prasyarat laboratorium dan $50 \%$ kurang yang dicirikan laboratorium digunakan sebagai ruang kelas/ tidak memiliki gedung/ruang laboratorium. Secara keseluruhan hambatan dalam bidang sarana prasarana sebesar 56\% dikategorikan dalam kelompok cukup banyak. Langkahlangkah untuk mengatasi hambatan sarana prasarana laboratorium diantaranya adalah menggunakan gorden untuk memperoleh ruang gelap, melakukan persiapan kegiatan laboratorium di ruang lain atau menggunakan ruang kelas yang akan melakukan kegiatan laboratorium. Langkah-langkah guru fisika mengatasi hambatan ini dikategorikan cukup baik, yaitu sebesar $70 \%$.

b) Pengelolaan laboratorium merupakan salah satu faktor hambatan dalam kegiatan laboratorium, yang meliputi kelengkapan adminitrasi laboratorium antara lain buku inventaris alat dan bahan, buku perawatan alat dan bahan, buku pedoman penggunaan alat, buku rancangan kegiatan laboratorium yang diatas $50 \%$ telah dimiliki oleh sekolah. Tetapi hanya $25 \%$ dari sekolah yang memiliki buku laporan hasil kegiatan laboratorium, ini menunjukan bahwa sebagian besar sekolah masing menganggap kegiatan laboratorium merupakan kegiatan yang tidak terlalu penting. Secara keseluruhan hambatan dalam pengelolaan laboratorium sebesar $70 \%$, dikategorikan cukup banyak. Langkah-langkah mengatasi hambatan pengelolaan diantaranya melakukan penataan administrasi lebih baik/ melengkapi, berusaha mengikuti seminar/pelatihan laboratorium, dan berusaha melakukan kerjasama antara instansi untuk mengembangkan laboratorium. Secara keseluruhan langkah-langkah guru mengatasi hambatan sebesar 57\%, dikategorikan cukup baik.

c) Dari segi hambatan alat dan bahan kegiatan laboratorium, sebanyak 19.8\% alat dan bahan praktikum dalam ketegori baik, 39.6\% dalam kategori cukup baik, dan $40.5 \%$ dalam ketegori kurang. Ini disebabkan sebagian besar alat dan bahan praktikum tidak mencukupi/rusak. Alat yang rusak alat mekanika dan gelombang, optic dan elektromagnetik. Alat-alat yang rusak ini disebabkan kurangnya penataan dan perawatan juga disebabkan ketika melakukan kegiatan laboratorium, siswa tidak memperoleh spesifikasi alat-alat, kurangnya penataan dan perawatan. Secara keseluruhan hamabatan alat dan bahan kegiatan laboratorium diktegorikan cukup banyak, sebesar 56\%. Langkah-langkah yang dilakukan untuk mengatasinya antara lain melakukan kegiatan laboratorium secara bergilir atau secara demonstrasi. Jika laboratorium tidak memiliki alat, 45\% guru membuat alat sederhana dan sisanya membeli alat baru/ tidak membuat alat sederhana. Secara keseluruhan langkahlangkah guru fisika dalam mengatasi hambatan alat dan bahan kegiatan laboratorium dalam kategori cukup baik, sebesar $58 \%$. 


\section{KESIMPULAN DAN SARAN}

Berdasarkan informasi dan analisis yang dilakukan kesiapan guru fisika kota mataram dalam kegiatan laboratorium dikategorikan cukup siap, yang dapat dilihat dari:

a. Kompetensi guru fisika SMA dalam

kegiatan laboratorium

Berdasarkan hasil studi dokumentasi rancangan kegiatan laboratorium yang disusun guru, dapat disimpulkan bahwa kompetensi guru fisika dalam kegiatan laboratorium cukup baik, yaitu sebesar $52 \%$.

b. Kondisi sarana prasarana laboratorium fisika

Sesuai Permendiknas no.24 tahun 27, sarana prasarana laboratorium fisika di kota Mataram dalam kategori cukup baik, yaitu sebesar $63.1 . \%$. Dimana sebanyak $36.9 \%$ saran prasaran laboratoriumSMA di Kota Mataram dalam kategori baik, $26.2 \%$ berkategori cukup baik dan $36.9 \%$ dalam kategori kurang.

c. Faktor-faktor penghambat kegiatan laboratorium

Faktor-faktor yang termasuk penghambat kegiatan laboratorium adalah gedung/ruang sebesar 56\% dalam ketegori cukup banyak, pengelolaan laboratorium sebesar $70 \%$ berkategori cukup banyak, dan alat dan bahan kegiatan laboratorium, sebesar 56\% berkategori cukup banyak.

d. Langkah-langkah dalam mengatasi

hambatan kegiatan laboratorium

Langkah-langkah untuk mengatasi hambatan sarana prasarana laboratorium dikategorikan cukup baik, yaitu sebesar $70 \%$, dari segi pengelolaan laboratorium berkategori cukup baik, sebesar $57 \%$ dan langkah-langkah mengatasi hambatan alat dan bahan kegiatan laboratorium sebesar $58 \%$, dalam ketegori cukup baik.

Saran yang dapat diberikan dari hasil penelitian ini adalah diharapkan agar instansi terkait lebih sering memberikan pelatihan terhadap kegiatan laboarotium untuk meningkatkan kompetensi guru dalam kegiatan laboratorium khususnya kegiatan prosedur percobaan inquiri atau keterampilan proses dan alat evaluasi kegiatan laboratorium.

\section{DAFTAR PUSTAKA}

Alit, Made. 2011. Prosedur Pengelolaan Laboratorium IPA di Sekolah. P4TK IPA Bandung.

Badan Penelitian dan Pengembangan. 2012. Dokumen Kurikulum 2013. Jakarta: Kemendikbud.

Brotherton, P.N., (1995). Science Process Skills: Their nature and interrelationships. "Journal on Science and Technological Education." Vol 13, No. 1.

Dahar, R.W. 2011. Teori-teori Belajar \& Pembelajaran. Jakarta: Erlangga.

Nur, M. 2004. "Penerapan Ide-ide Inovatif Pendidikan MIPA dalam Seting Penelitian." Makalah dipresentasikan pada Seminar Nasional Pendidikan MIPA yang diselenggarakan oleh FMIPA Unnes pada tanggal 28 Februari 2004.

Rustad, S.A Munandar, \& Dwiyanto. 2004. Analisis Prasarana dan Sarana Pendidikan SD/MI, SMP/MTS, dan SMA/SMK/MA. Jakarta: Balitbangnas, Departemen Pendidikan Nasional.

Sriyono \& A. Hamid. 2003. "Pemanfaatan Laboratorium dalam Pembelajaran Fisika SMU." Makalah dipresentasikan pada Seminar Nasional Pendidikan MIPA yang diselenggarakan oleh FMIPA Unnes pada tanggal 22 Februari 2003.

Sumintono, B. 2010. "Pengajaran Sains dengan Praktikum Laboratorium: Perspektif dari Guru-guru Sains SMPN di Kota Cimahi". Jurnal Penelitian Pendidikan, Vol 15, No. 2.

Wenning, C. J. 2005. "A Physics Teacher Candidate Knowledge Base." Journal Physics Teacher Education. 2 (3).

Wiyanto. 2008. Menyiapkan Guru Sains Mengembangkan Kompetensi Laboratorium. Semarang: Unnes Press. 